\title{
Sanat Sosyolojisi Açısından Nuruosmaniye Camisi
}

\author{
DOI: $10.26466 /$ opus.866536
}

\section{Duygu Ilkhan Söylemez}

* Öğr. Gör. Dr., Selçuk Üniversitesi, Sosyal Bilimler Meslek Yüksekokulu, Konya/Türkiye E-Posta: duyguilkhan@gmail.com

ORCID: 0000-0002-5707-1542

\section{Öz}

Nuruosmaniye Camisi, 1748-1755 yılları arasında inşa edilmiş dönemin en önemli ticaret merkezi olan Kapalıçarşı girişinde yer alan ve baroklaşmaya doğru bir gidişatın görüldü̆̆̈̈ ilk camidir. Bu araştırmanin temel amaci, Nuruosmaniye Camisi kültürel aidiyet kodlar ile sanatın sosyolojik olarak diyalektik bir yöntemle irdelenmesidir. Burada analitik önermelerin sentetik önermeler ile ne ölçüde özdeşleşeceği toplumsal beklentiler ve toplumun sanat anlayışı ile yakından ilgilidir. Bir diğger sosyolojik faktör ise Nuruosmaniye'nin yapıldığı yıl ile bugün arasındaki kültürel değişimdir. Nuruosmaniye Camii ile ilgili toplumsal alımlamalar ve anlamlandırmalar arasındaki ilişki dairesel ve doğrusal olmak üzere iki yönlüdür. Caminin görünen sanatsal yönü doğrusal, fizik ötesi ise daireseldir. Bu nedenledir ki sanatsosyolojisi olarak değerlendirmeler analitik önermeler ile sentetik önermeler arasındaki medcezir gibidir. Araştırmada sanat sosyolojisinin temel amacl, insanın özünde var olan güzellikleri görme eğiliminin, ruhun manevi doyuma ulaşmasındaki katkının düşünsel kısa bir analizidir. Nuruosmaniye Camisi, insanı içerisinden dışına kadar kuşatacak estetik bir sanat anlayışının simgelemektedir. Bu sanat anlayışı, tüm toplum hayatına yayılacak manevi bir kültür oluşumunu da beraberinde getirmektedir.

Anahtar Kelimeler: sanat sosyolojisi, sanat tarihi, Nuruosmaniye Camisi 


\title{
Nuruosmaniye Mosque in Terms of Art Sociology
}

\begin{abstract}
The purpose of this research is to examine the cultural belonging codes of Nuruosmaniye Mosque and art with a sociologically dialectical method. Here, to what extent analytical propositions will be identified with synthetic propositions are closely related to social expectations and the art understanding of society. Another sociological factor is the cultural change between the year the Nuruosmaniye was built and today. The relationship between social receptions and interpretations about Nuruosmaniye Mosque is two-way, circular and linear. The visible artistic aspect of the mosque is linear, while its beyond physics is circular. For this reason, evaluations as art-sociology are like the median between analytical propositions and synthetic propositions. The main purpose of art sociology in this research is a short intellectual analysis of the tendency to see the inherent beauty of the human being and the contribution of the spirit to spiritual satisfaction.
\end{abstract}

Keywords: sociology of art, art history, Nuruosmaniye Mosque 


\section{Giriş}

Sanatı siyaset dışı estetik değerler ile değerlendirmenin algı sınırları, sosyoekonomik, diakronik, demografik yapı, lokasyon ve epistomolojik bileşenler ile mümkün olabilir. Zira "sanat" tarihi süreçte "yeniden üretim" tezahürü içerisinde, toplumun kültürel, zihinsel algılarına ve anlamlandırmalarına katkı sağladığı âşikardır. Bu durum toplumu sanatın metafizik ve onkolojik unsurlarını keşfetmeye yönlendirecektir.

Nuruosmaniye Camisi gerek mimarisi, gerekse süslemeleri ile batı ve islam kültürü sentezinin bütünleşmesi olarak görebiliriz. Camiler toplumun zahiri ile batınî arasındaki bağlantıyı bulup çıarmasında eğitici bir öneme sahiptir.

İnsanlık tarihindeki her gelişme ve değişim toplumların yaşam tarzları üzerinde yen bir yön vermiş olup (Söylemez ve Şahin, 2018: 323) bu değişim ve gelişmeler yeni firsatlar sunar ve insanın kendini keşfederek kentsel yaşamda yeni sayfalar açmasına yardımcı olur (Söylemez, 2021: 85). Demografik yapısı itibarı ile camii çevresinde yaşayan insanlar, tarihi süreç içerisinde değişim göstermiş olup, "sanat" 1 üretim ve tüketim kavramaları ile, modernlik ve materyalist odaklı fikirlerle görmeye başlamışlardır. Sosyolojik olarak "sanat", tarihi anlayış içerisinde değişime uğramakla birlikte, sanat toplum ilişkisi bakımından "sanat" sanat içindir veya sanat toplum içindir bağlamında değerlendirilmesi, düşünsel ve duygusal olarak fiziki olanın dışına çıkılmaktadır/çıkılmamaktadır.

Sosyolojik olarak fiziki olanın metafiziğini bulmak insanın doğasında bulunan meraklarından, anlayışlarından kaynaklanmaktadır. Zira toplumlar ibadethaneleri ile yaşarlar ve bu nedenledir ki oralarda sanatın mükemmeliyeti zuhur eder.

\section{Araştırmaya İlişkin Yöntem}

Nuruosmaniye Camisini kültürel aidiyet kodları ile sanatın sosyolojik olarak diyalektik bir yöntemle irdelenmesi temel amaç olarak belirlenmiştir. Burada analitik önermelerin sentetik önermeler ile ne ölçüde özdeşleşeceği toplumsal beklentiler ve toplumun sanat anlayışı ile yakinen ilgilidir. Bir diğer sosyolojik faktör ise Nuruosmaniye'nin yapıldığı yıl ile bugün arasındaki kültürel değişimdir. 
Nuruosmaniye Camii ile ilgili toplumsal alımlamalar ve anlamlandırmalar arasındaki ilişki dairesel ve doğrusal olmak üzere iki yönlüdür diyebiliriz. Caminin görünen sanatsal yönü doğrusal, fizik ötesi ise daireseldir. Bu nedenledir ki sanat-sosyolojisi olarak değerlendirmeler analitik önermeler ile sentetik önermeler arasındaki medcezir gibidir.

Araştırmada sanat sosyolojisinin temel amacı, insanın özünde var olan güzellikleri görme eğiliminin, ruhun manevi doyuma ulaşmasındaki katkının düşünsel kısa bir analizidir.

\section{Sanat Sosyolojisi Olarak Fiziki Dünyanın Metafiziği Üzerine Yaklaşımlar}

Sanatı sosyolojik olarak anlama ve anlamlandırma çabası, çıplak gözle görünen gerçekliğin ötesinde sanatın metafiziği nerede sorusunda yatmaktadır. Bu bakış açısı kültürel, geleneksel ve zamana bağlı olarak yorumlama biçimi olup, biz buna disiplinler arası bir bakış açısı da diyebiliriz. Mülayim'e göre ( 2012: 100); sanat sosyolojisi "çok disiplinli olmanın ötesine geçerek ve bilim felsefesini de zorlayarak gelişecektir" Ne var ki bağımlı dünyada kültürel aidiyet kodlarının değişimi veya erozyona uğraması, kuşkusuz bu değişim kendisini sanat anlayışında da gösterecektir.

18. yüzyıla kadar sanat sosyolojisi disiplininin odak noktasını felsefe oluşturmaktadır. Sanatın sosyal yapı içerisindeki yeri, irdelenmesi, diğer disiplinler ile etkileşimi, fonksiyonu, metodolojisi 19. yüzyılda farklılaştığını söyleyebiliriz (Ulusoy, 1993, s.248). Ancak sanat sosyolojisinin amacı sanat üzerindeki gizem perdesini aralamak ise, sanat tarihçileri sosyolojiyi fazlasıly genellemeci ve belirlemeci bulmakta ve sadece sanat eserlerinin içsel niteliklerine vurgu yapmaktadırlar (Değirmenci, 2017, s.5). Her ne kadar bu düşünce tarzına zahiri olarak olumlu bakılsa da, sanat toplumla vardır. Zira sanat eser toplumun bakış açısı ile "yeniden üretimden" başka bir şey değildir. Burada toplum bireylerinin "yeniden üretimi" diye nitelememiz analitik önermeler içerisinde sanatın metafizik ve ontolojik unsurları ile ilgilidir. Her ne kadar metafizik ve ontolojik kavramlar birbiri ile çakışsa da birbirinden mutlak bir şekilde ayırt edilmelidir. 


\section{Sanat Sosyolojisi Açısından Bilim İnsanlarının Genel Yaklaşımları}

a) Sanat eserleri içinde bulundukları sosyal koşullarla belirlendiği ve onların sonuçları olduğudur. Bu nedenledir ki üretim biçimindeki değişmeler, sanatın tarihi ekonomik konuma göre şekil alır (Karl Marx bkz. Ulusoy, 1993, s.249). Sanat bir bakıma toplumun yansıması olarak da görülmektedir. Zira, her kültür basamağı kendi toplumsal değerleri açısından anlamlı bir sanat geleneğini ortaya koyar (Mülayim, 2012, s.107)

b) Max Weber ise, sanatın kaynağın dine bağlayarak, din ve sanat arasındaki nedensel ilişkiyi ön plana çıkarır. Dinin sanatsal aktiviteleri harekete geçirdiğini söyler (Ulusoy, 1993, s.251).

c) 18. Yüzyıl'ın ikinci yarısında devrim niteliğindeki değişimle modern bir orta sınıf oluşmuş ve yeni bir sanat akımı doğmuştur. (Ulusoy, 1993, s.250)

d) 1800'lerde ortaya atılan bir diğer görüş, sanatın ve edebiyatın politik düşüncelerle uyum içerisinde olduğudur (Ulusoy, 1993, s.252).

e) Antik Yunanistan'da ise sanat taklitle özdeş bir temsil aracı olarak görülür.

f) Sanatı ticari maksatla metanın dağıtımı ve reklamı için gören birçok görüş de ortaya atılmıştır (Değirmenci, 2017:3).

g) Immanuel Kant "yargı yetisinin eleştirisi" adlı eserinde kendi fikri ile kavramsallaştırılan sanat eseri arasında bir bağlantı kurar (Değirmenci, 2017:4). Ona göre sanattaki temel unsur özgürlük ve özgünlüktür. Sanatta kuralları koyan, araştıran sanatçının kendisidir ve doğayı asla taklit etmez. Zira doğa zaten onun kendisidir. Bu nedenle Kant'a göre tutkun fiziksel varlıkta değil düşüncede yatar.

Sanatın sosyolojik olarak değerlendirmeleri konusunda burada zikredilen/edilmeyen bilim insanlarının görüşleri bir bakıma "sanatı", zamanı anlamlı kılan hareketlilik ve üretkenlik olarak sağlam bir düşünce temelinde kurgulamışlardır. Sanatı diyalektik bakış açısı ile değerlendirmişler, toplumsal bir farkındalık ile sanat anlayışına ilişkin ontolojik/metafizik unsurları ve materyalist düşünce tarzının insan tarafından idrakini sağlamışlardır.

Sanatın siyasal otorite tarafından belirlenmesi veya materyalist düşüncenin hâkim olması, özgür düşünceyi yok eder ve bu tahribat nihilizme yol açabilir. 


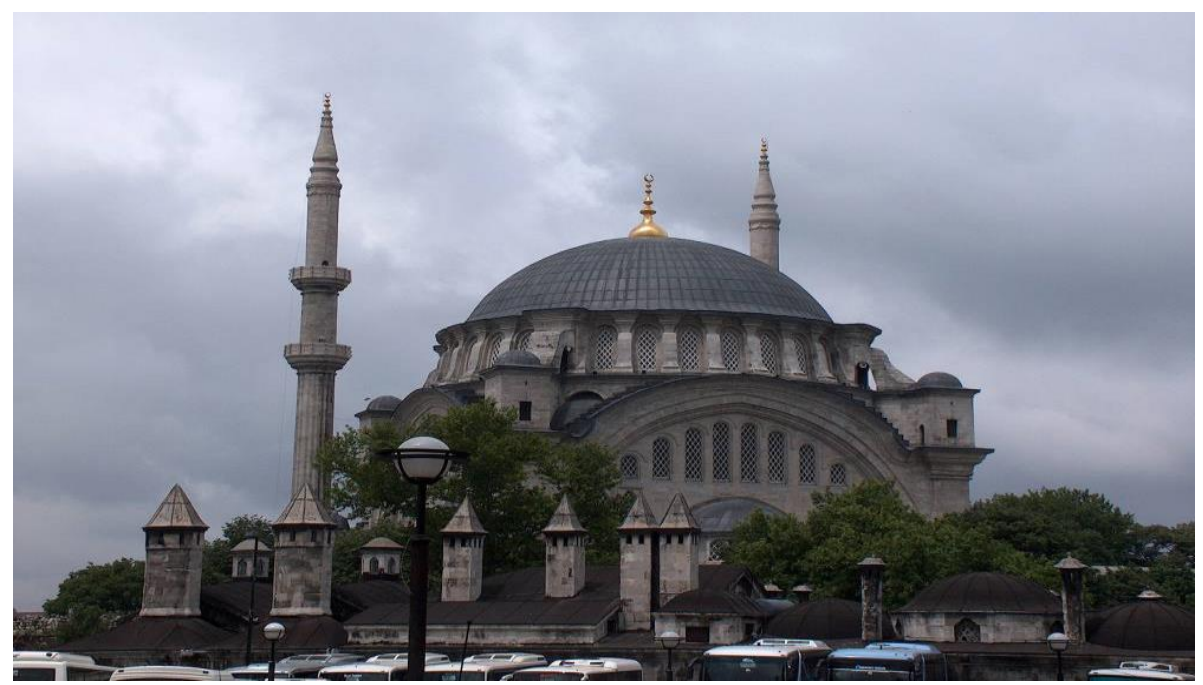

Fotoğraf 1. Nuruosmaniye Camisi genel görünüm

\section{Nuruosmaniye Camisinde İslam ve Batı Sanatına İlişkin Örneklemeler}

Nuruosmaniye Camisi (Fotoğraf 1), harimi tek kubbeyle örtülü, klasik dörtgen bir camiidir. Bir başka deyişle camide mekânsal bir barok özelliği görülmemektedir (Ögel, 1992, s.270). Buna mukabil, 1753'te cami inşaatını yerinde gören Le Roi adlı Fransız bir mimar kubbenin yapımı sırasında Rum mimarın kullandığı basit ve kullanışlı yöntemi övmektedir (Kuban, 1981, s.273). Yarım daire kasnak üzerine oturan kubbede mekân boyutlarına göre Sinan dönemine kıyasla kubbe basıklığının azaldığı, Avrupa'daki aynı dönem yapılarının kubbe yüksekliklerine yaklaşıldığı görülmektedir (Bakır,1999, s.267). Genel olarak Nuruosmaniye Camisine baktığımızda baroklaşmaya doğru bir gidişatın görüldüğü ilk camidir. İlklerin görüldüğü Nuruosmaniye Camisi kendisinden sonra inşa edilen camiler için örnek teşkil etmektedir. Örneğin; hünkâr mahfiline giriş dıştan rampalı olup L şeklinde pencereli bir koridordan oluşan bir geçiş ile sağlanmaktadır (Cezar, 2002, s. 154) (Fotoğraf-2). Yapıyı aydınlatan pencereler alçıdan ve barok stilindedir (Doğru, 1987, s.154). Barok üslubun etkisiyle meydana gelen yapının iç avlusu klasik plan esasından farklı olup, ortasında şadırvan yoktur ve avlu yarım oval şeklinde yapılmış on iki sütuna dayanan on dört kubbeli olarak inşa edilmiştir. Bu avludaki revakları ve kubbeleri taşıyan büyük mermer sütunlar Bergama'dan ve muhtemelen Kızıl Avlu adlı Roma yapısından getirtildiği söylenir (Tanyeli ve 
Tanyeli, 1989, s.27) (Kuban, 1995, s.160). Caminin diğer bir özelliği de mihrabın planda bir çıkıntı teşkil eden nişe yerleştirilmiş olmasıdır. Gabriel'in bu asır camilerinin karakteristiği olarak gösterdiği bu çıkıntı genel olarak diğer camilerde dikdörtgendir. Burada poligonal olarak çıkmakta ve yarım kubbe ile örtülerek apsidal bir şekil almaktadır (Kuban, 1954, s.121) (Fotoğraf 3).

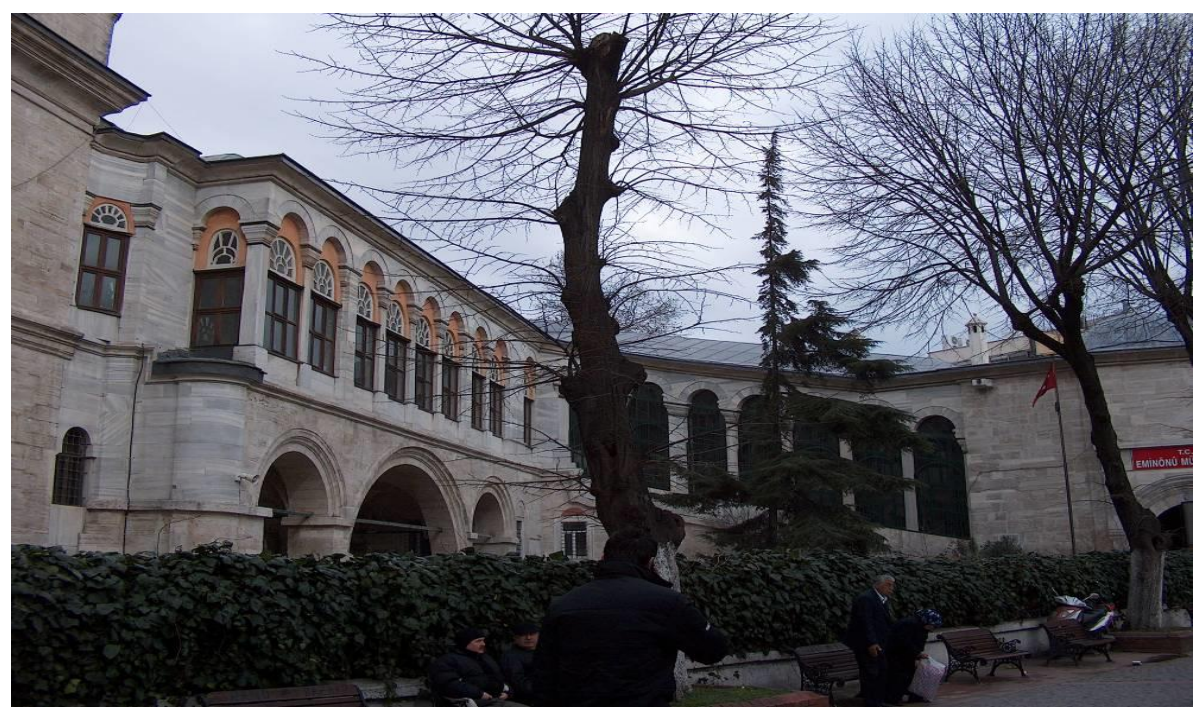

Fotoğraf 2. Nuruosmaniye Camisi hünkâr mahfili rampası

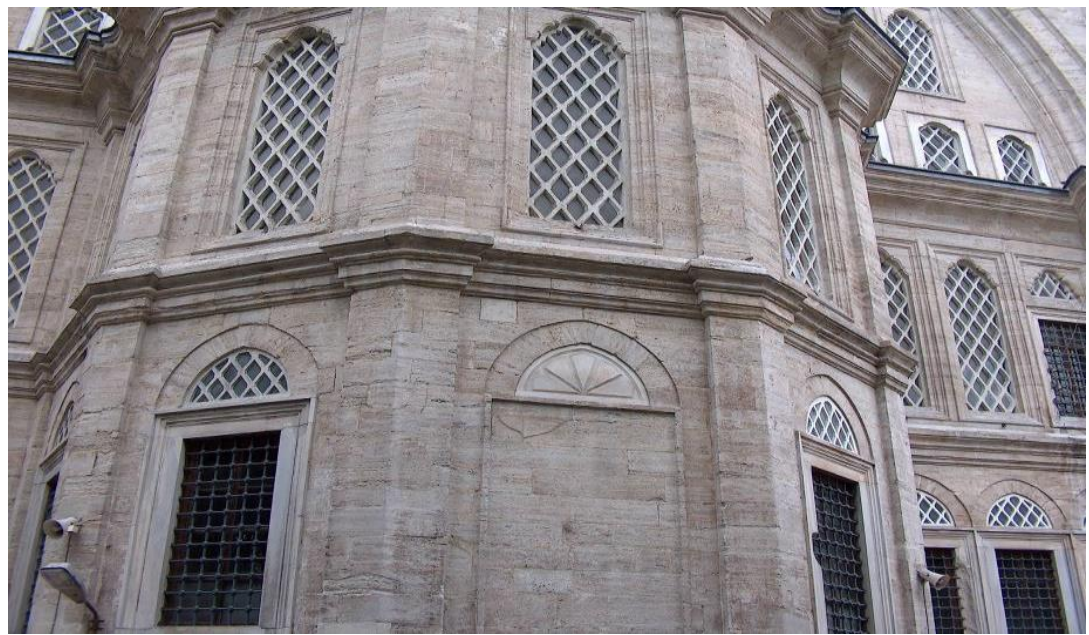

Fotoğraf 3. Nuruosmaniye Camisi mihrap çıkıntısı 
Selçuklu, klasik ve geç Osmanlı döneminde kullanılan bitkisel süslemelerden birisi olan "Palmet" ilk örnekleri Babil'de II. Nabukadnezar'ın (M.Ö. 605562) yaptırdığı yazlık sarayın taht salonu duvar bezemelerinde görülmüştür (Anonim, 1997, s.1424). Farklı uygarlıklarda görülen palmetler özellikle Sümer, Mısır, Yunan ve Roma eserlerinde kullanılmış, Helenistik akım yoluyla da doğu sanatına girmiş ve Abbasilerle birlikte İslam sanatında yaygın olarak kullanıldığı görülmüştür (Özbek, 2002, s.534). M.Ö. 3000 yılında Mısır'da görülen palmet motifinin 2000 yılında Anadolu'ya geçmiştir (Kuru (Çakmakoğlu), 1997, s.39). Kronolojik açıdan özde aynı olan palmetler, çeşitli uygarlıklarda bazı farklılıklar gösterirler. Bitkisel motif olarak süslemelerde yer alan palmetin literatürde değişik tanımlarını saptayabiliriz: Palmetin hurma veya palmiyeden stilize edildiğini ve Kur'anda cennette tasvir olunan hurma ağacından ilham alınarak yapılmıştır (Özbek, 2002, s.533). Nuruosmaniye Camii cümle kapısı duvar kalınlığı içindeki yan nişlerin en alt bölümünde yer alan palmetler ters dönmüşs şekilde tasarlanmıştır (Fotoğraf 4).

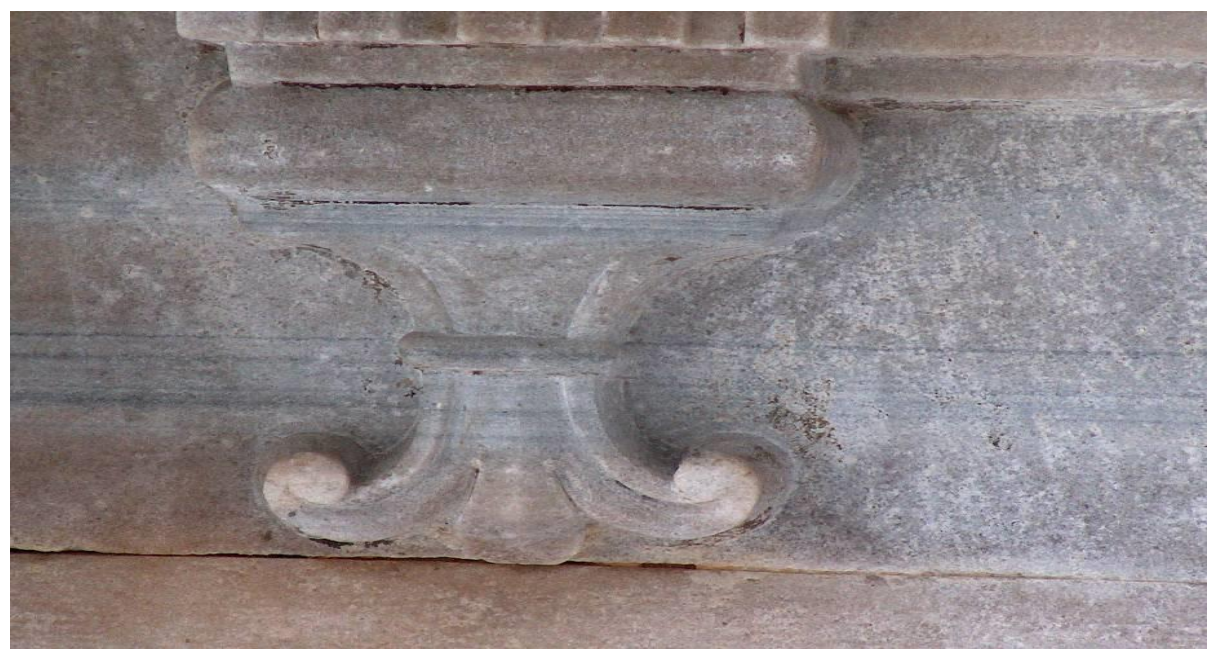

Fotoğraf 4. Nuruosmaniye Camisi yan nişlerin en altındaki ters palmet motifi

18. ve 19. yüzyılın hem Avrupa hem de İslam coğrafyası olan Anadolu'da en geniş yer bulduğu süsleme öğelerinden birisi de "Akantus Yaprağıdır." İlk olarak eski Mısır'da sütun başlıklarında görülen akantus motifi Emeviler yolu ile Roma Bizans'tan İslam sanatına girmiş ve Yunan ve Roma sanatında da sıklıkla kullanılmıştır. Ancak bazı kaynaklarda bu üslubun ilk kez antik 
Yunan sanatında kullanıldığı belirtilmektedir (Kürkçüoğlu, 1998, s.177; Sözen ve Tanyeli, 1999, s.15). Nuruosmaniye Camisi cümle kapısındaki barok mukarnasta, cümle kapısının duvar kalınlığı içine açılan yan nişlerin alınlığında ve güneybatısındaki çeşmede akantus yapraklarına rastlanmaktadır. Cümle kapısındaki dokuz bölümlü mukarnasın her bir bölümünde yaprak sayıları ve şekilleri farklı akantuslar vardır. Bu motifin benzerini yine aynı caminin avluya girilen doğu ve batı kapısında görmekteyiz. Cümle kapısının duvar kalınlığı içine açılan yan nişlerin alınlıklarında ve sütunce başlıklarındaki akantuslarda, yaprak uçlarının içbükey şeklinde kıvrıldığı görülür (Fotoğraf 5-6). Güneybatısında yer alan çeşmenin yanlarındaki küçük sütuncelerin başlıklarında da akantuslar yer almaktadır (Fotoğraf 7). Burada görülen akantusların benzerleri yine aynı caminin cümle kapısındaki sütunce başlıklarında karşımıza çıkmaktadır.

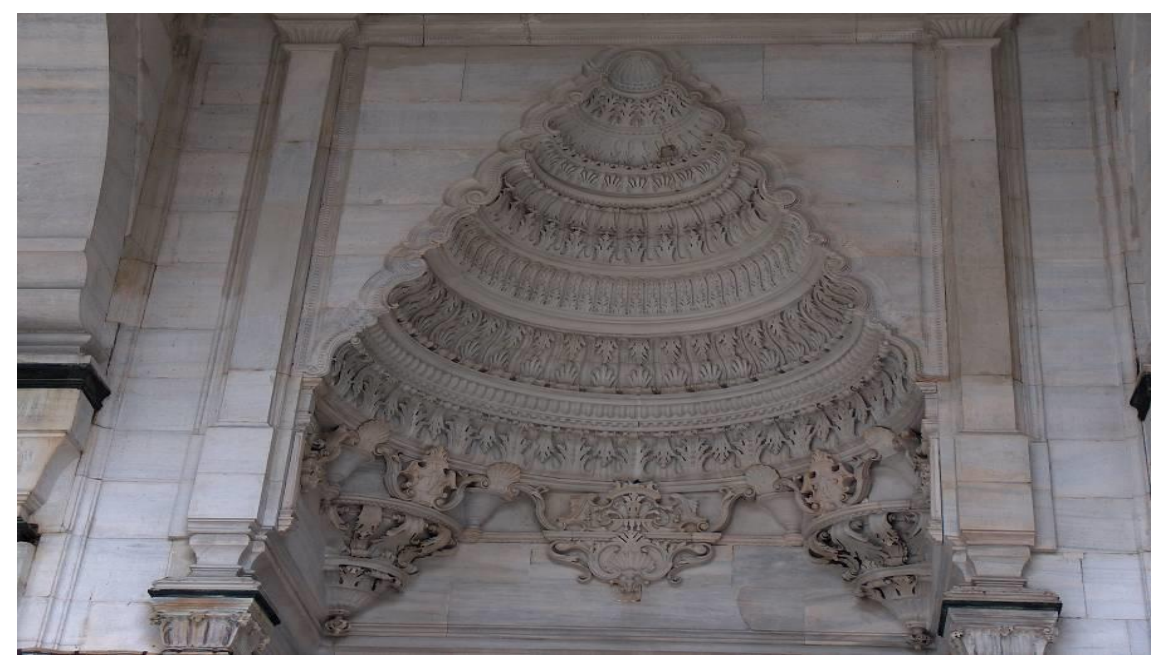

Fotoğraf 5. Nuruosmaniye Camisi cümle kapısının barok mukarnaslı kavsarası 


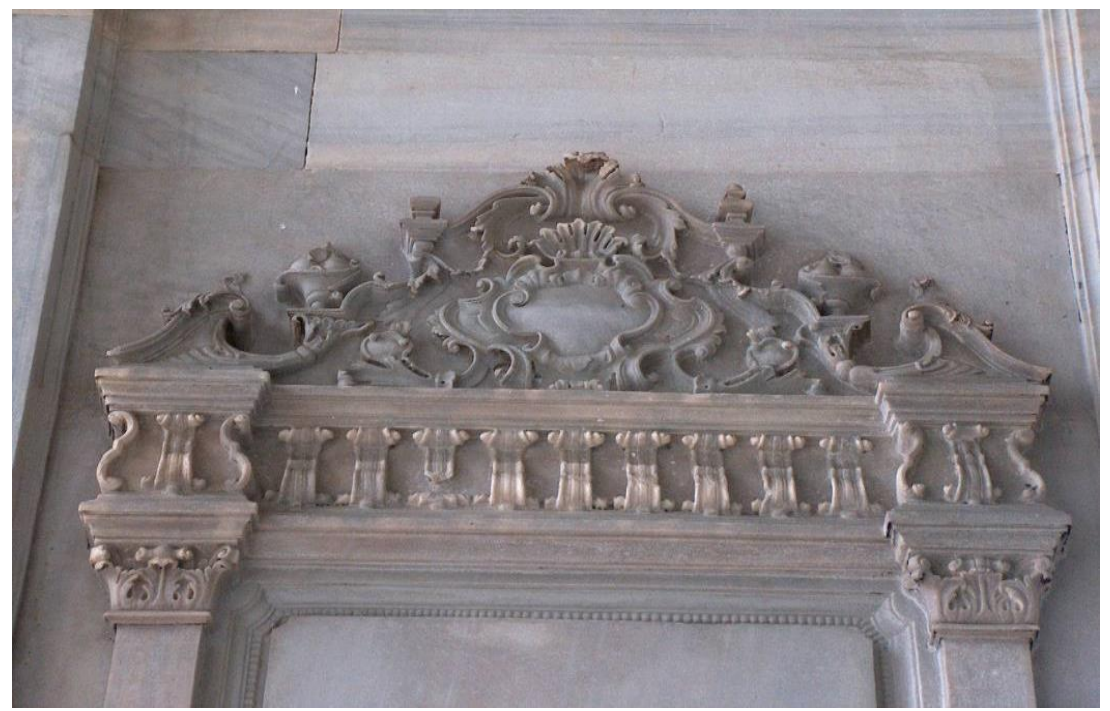

Fotoğraf 6. Nuruosmaniye Camisi yan nişlerin alınlığı

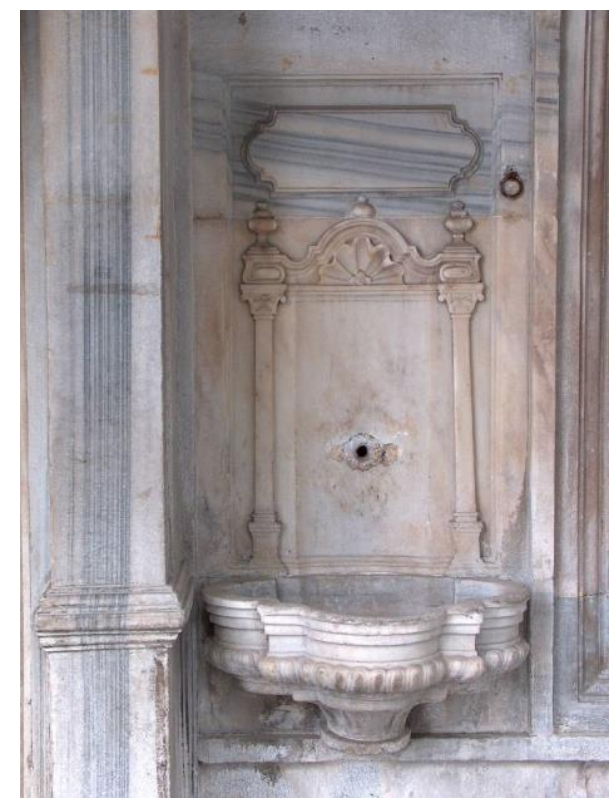

Fotoğraf 7. Nuruosmaniye Camisi güneybatı cephesindeki çeşme 
Antik Yunan ve Roma dönemi yapılarında görülen "Diş Sırası" süslemeleri Osmanlı mimarisinde de yerini almıştır. Eşit aralıklarla yerleştirilmiş yukarıdan aşağıya doğru düşey şekilde sarkan küçük dikdörtgen veya karelerden oluşan çıkıntı ve yivlerden müteşekkil dişe benzer süslemelerdir. Bu süslemeler dor düzeni tapınaklarında trigliflerin altında ve üstünde, metop'unda üstünde görülmektedir (Hasol, 2002, s.134). Nuruosmaniye Camisi'nin aşağıdan yukarıya doğru daralan ve dokuz sıra olan barok mukarnaslı cümle kapısının birinci sırasında, kavsara yanlarındaki vazoların üstünde ve cümle kapısı üzerinden kubbeye geçişlerde yer alan vazoların üstünde diş sıraları bulunmaktadır (Fotoğraf 5 ve 8).

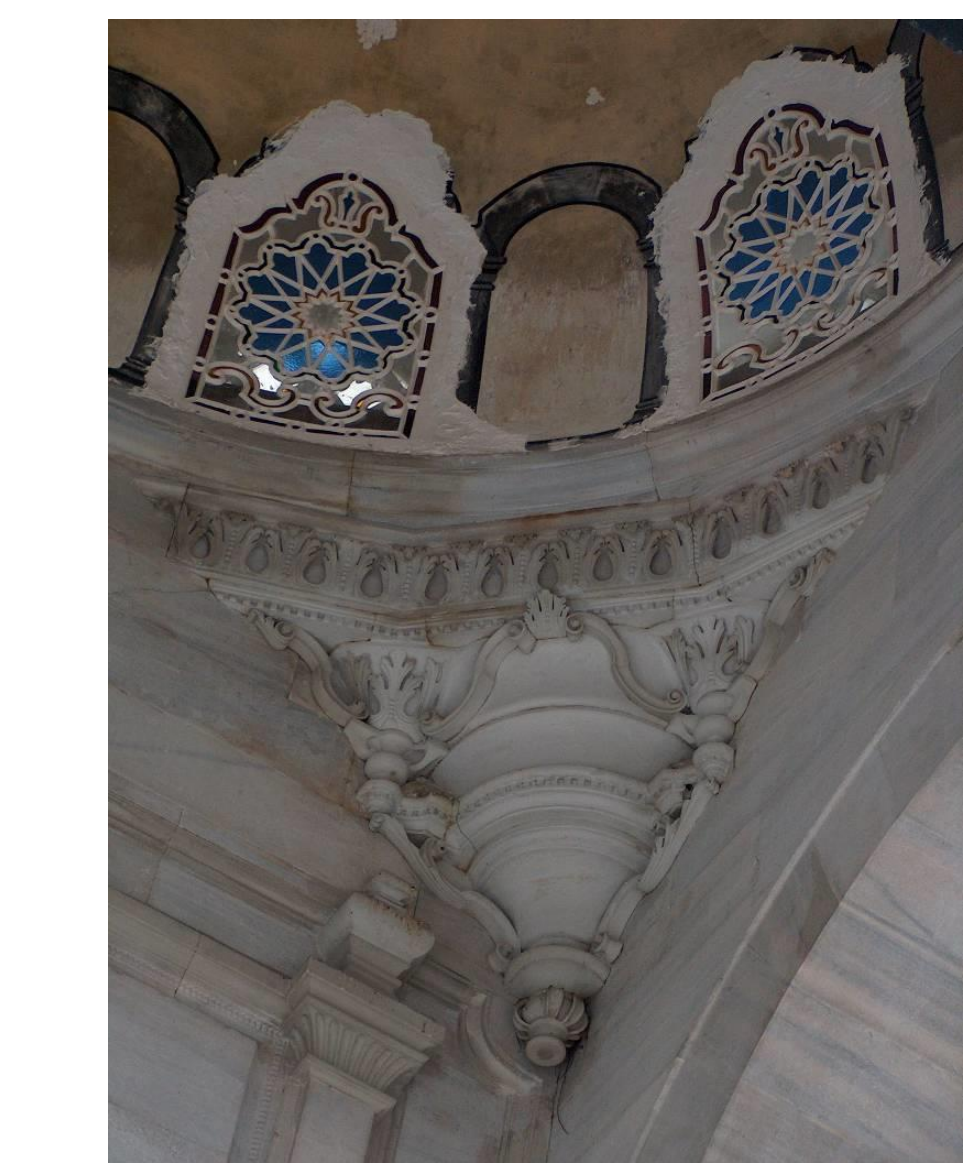

Fotoğraf 8. Nuruosmaniye Camisi cümle kapısından kubbeye geçişteki süsleme elemanlarn 
Geç dönem yapılarında sıklıkla karşımıza çıkan "S ve C kıvrımları" Avrupa mimarisinde de kullanılmış olup, Osmanlı mimarisinde barok üslubu adı altında zengin ve abartılı bir motif olarak benimsenmiştir. S- $C$ kıvrımlarının birlikte kompoze edilmesi binaya gösteriş ve hareketlilik kazandırmaktadır. Nuruosmaniye Camisi'nin hünkâr mahfil koridorundaki pencerelerde (Fotoğraf 9), galeri kemerlerinde (Fotoğraf 10), güneybatı cephede çeşmenin alınlığında (Fotoğraf 7), cümle kapısının kavsarasında, alınlığında, kavsara başlangıcındaki ve de kubbeye geçişlerde yer alan vazolarda (Fotoğraf 5 ve 8), cümle kapısı duvar kalınlığı içindeki yan nişlerin alınlığında da $S$ ve $C$ kıvrımları görülmektedir (Fotoğraf 6). Son olarak da saçak kornişleri de S- C kıvrımlı olarak yapılmışlardır.

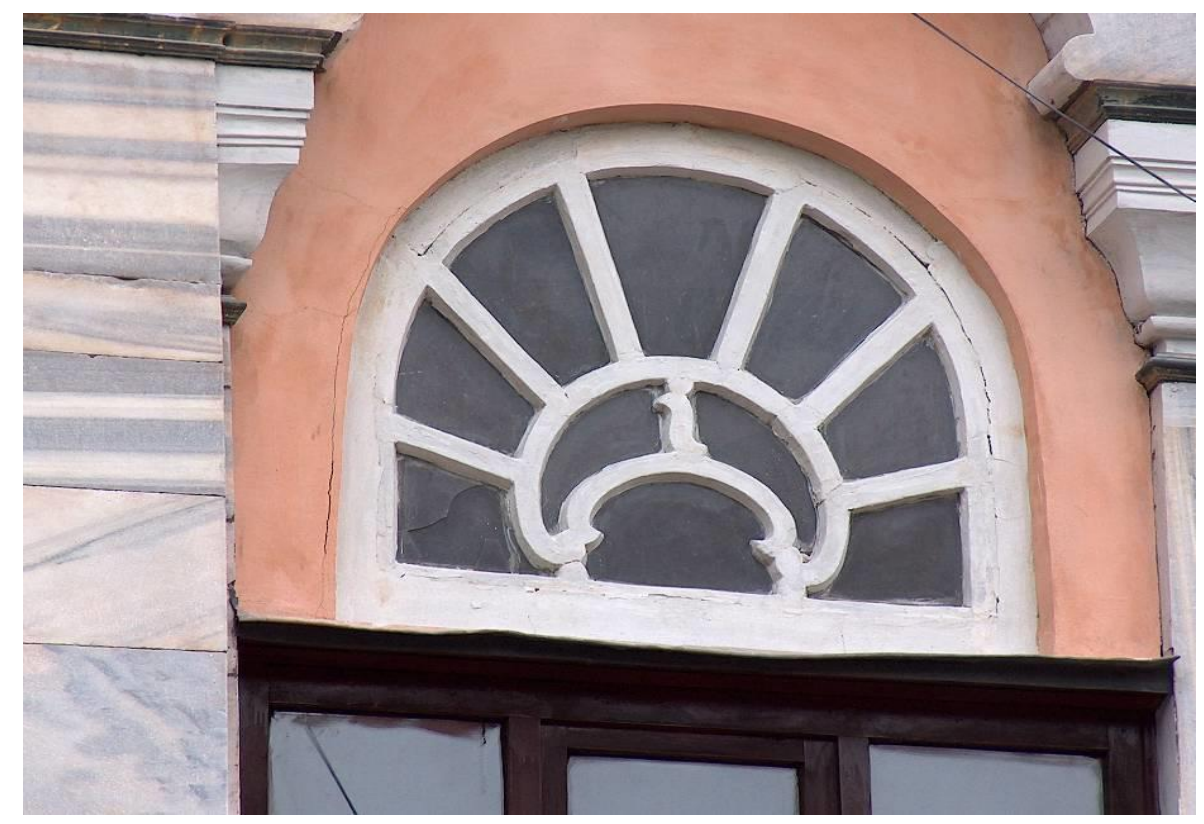

Fotoğraf 9. Nuruosmaniye Camisi hünkâr mahfil koridorundaki pencere 


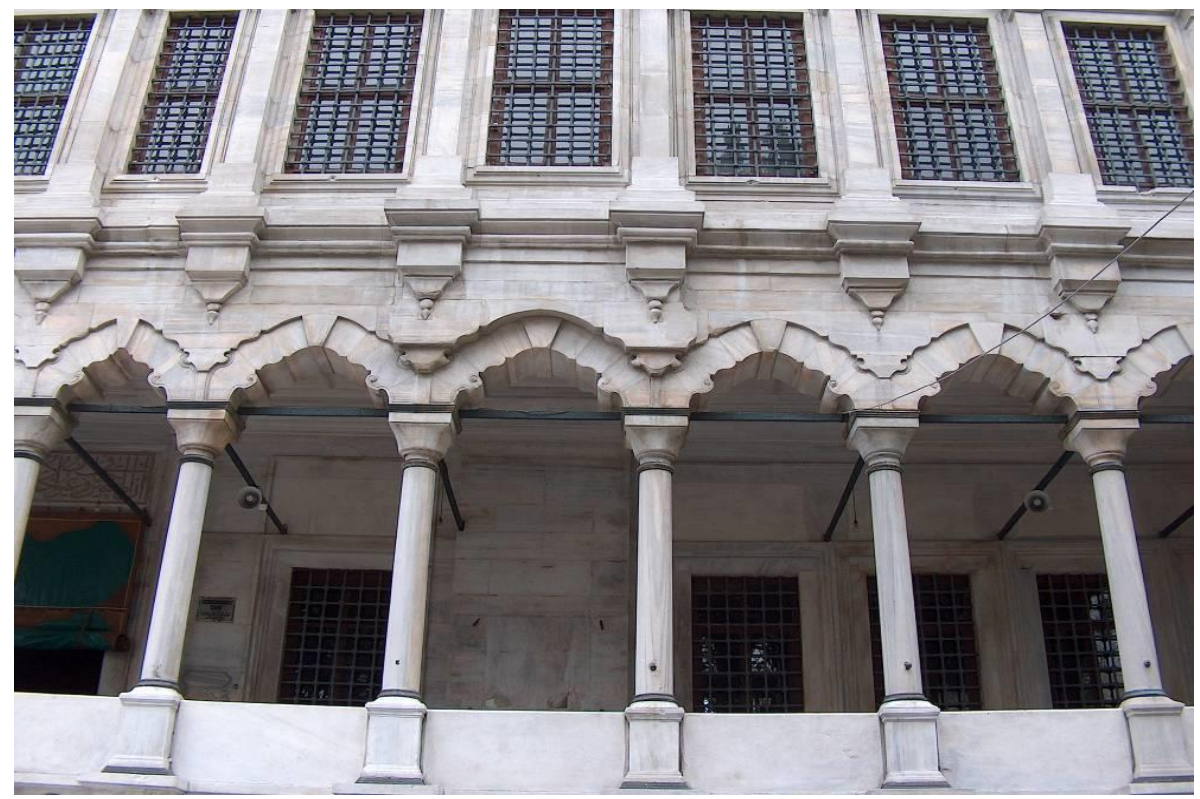

Fotoğraf 10. Nuruosmaniye Camisi dış yan galerisi sütunları ve kemerleri

İslam sanatında sıkça karşımıza çıkan, Petekler dizisi ya da hücreler halinde istiflenmiş görüntü veren "Mukarnas", bulunduğu yerde hem taşıyıcı hem süsleyici işlev gördüğünden statik ve plastik görevleri birlikte üstlenerek diğer süsleme elemanlarına göre çok farklı bir özellik taşır (Mülayim, 2006, s.126). Düşey bir yüzeyden daha taşkın bir yüzeye geçmek için yan yana ve üst üste gelen prizmatik öğeler, derece derece taşmalar yapacak biçimde istiflenmiş, 1şık-gölge oyunları ile özdeşen görünümü, mukarnasın İslam kültürünün yayıldığı tüm bölgelerde geliştiği görülmektedir (Hasol, 2002, s.332; Ödekan, 1997, s.1306). İslam sanatına özgü olan üç boyutlu mukarnas bezeme tekniğinin ilk olarak çıkışı hakkında farklı görüşler ileri sürülmüştür. 11. yüzyılda Mısır'da doğup oradan Orta Asya'ya doğru yayıldığının kabul edildiği gibi, en erken örneklerinin 9. ve 10. yüzyılda Nişabur'da bulunduğunu kabul edenlerde bulunmaktadır (Mülayim, 2006, s.126-127). İlk örnekleri alçı ve tuğladan olan mukarnasların daha sonra taş ve ahşap üzerine uygulandığı görülür. 11. yüzyıldan itibaren doğudan batıya doğru yayılan bu taşıyıcı ve süsleyici eleman bir gelişim göstermiş, 14. ve 15. yüzyıldan sonrada giderek karmaşık bir sistem gösteren mukarnasların, püskül ya da sarkıtlar halinde 
zenginleştiği görülmektedir (Mülayim, 2006, s.127). Geç dönem camileri içerisinde en farklı mukarnas Nuruosmaniye camisinde bulunur. Farklı bir biçim verilen cümle kapısı, dokuz bölümlü ve her bir bölümün akantus yapraklarıyla süslendiği, $S$ ve $C$ kıvrımlarından oluşan "barok mukarnas" türünün tek örneğidir diyebiliriz. (Fotoğraf 5).

Süsleme sanatında kullanım eşyası olan "Vazo", mimaride de karşımıza çıkmaktadır. Türklerin Çin ile olan yakın temasları sonucu bu motif Türk sanatına girmiş ancak, 13. ve 14. yüzyılda Anadolu'da fazla rağbet görmemiştir. 15. yüzyılda Osmanlı hâkimiyeti ile Anadolu ve İstanbul'da yeni sanat hareketi ile birlikte süslemelerde çiçek ve vazolar yer almaya başlar. 18. ve 19. yüzyıl 'da Batı ve Türk motiflerinin karışık kullanılması sonucu millî kimliğimize uygun yepyeni bir üslubun ortaya çıkmasına sebep olmuştur (Akar, 1969, s.268-269). Nuruosmaniye Camisi'nin (1755) cümle kapısında barok kavsaranın her iki yanında (Fotoğraf 10), kubbeye geçiş yerlerinde (Fotoğraf 8), duvar kalınlığı içindeki yan nişlerde de vazo ve kâse motifleri görülmektedir (Fotoğraf 6).

Selçuklu ve Osmanlı'nın her döneminde görülen, mimarinin bir parçası olmasının yanı sıra beden duvarlarını da güzelleştirip monotonluktan kurtaran diğer bir süsleme öğesi de "kuş evleri" dir. Hayvan sevgisinin göstergesi olan kuş evlerinin Türkiye'de oldukça erken tarihlere indirilen örnekleri vardır. Osmanlı dönemi bu tür yapılar açısından zenginlik arz etmektedir (Barışta, 2000, s.133). Nuruosmaniye Camisi'nin ağırlık kulesine, dilimli kemerleri olan pencereler açılmıştır. Bu pencereler aynı zamanda kuş evi olarak da tasarlanmıştır (Fotoğraf 11). Buna benzer örnek Doğu Beyazıt'taki İshak paşa Sarayında yer alan kuş evidir ve Nuruosmaniye Camisi'ndeki ile büyük benzerlik göstermektedir (Bektaş, 2003, s.58). 

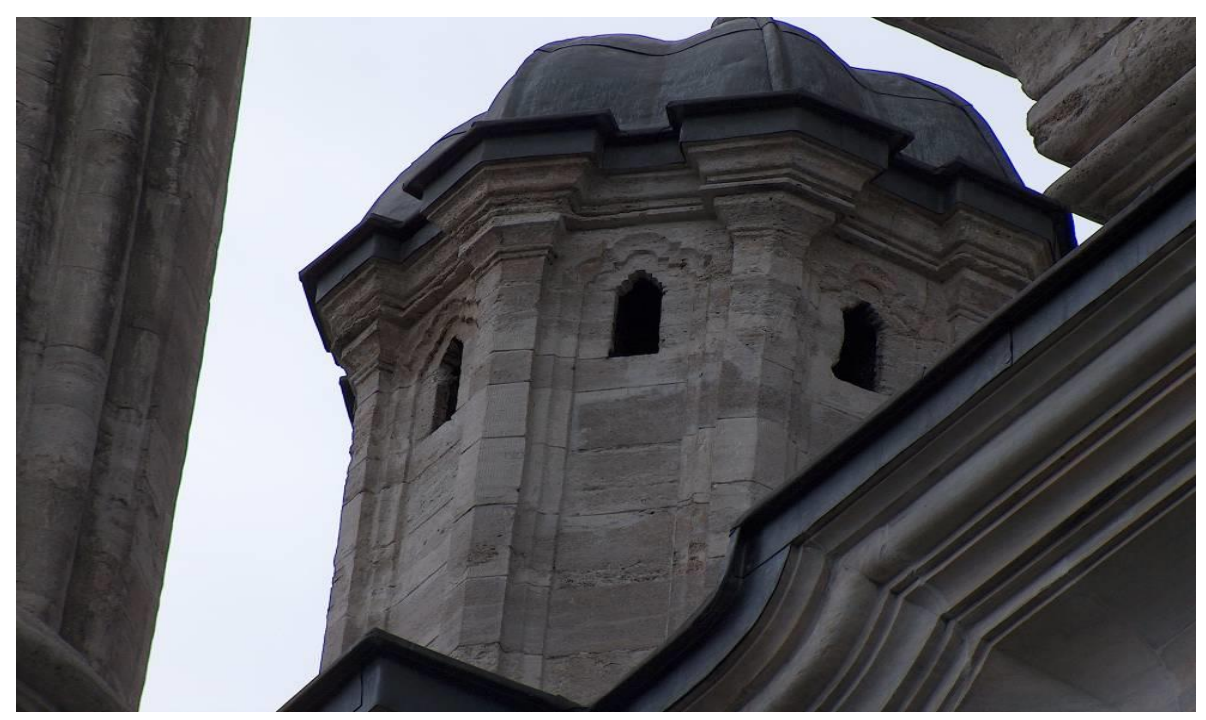

Fotoğraf 11. Nuruosmaniye Camisi ağırlık kulesi

Eski çağlardan itibaren farklı coğrafya ve kültürlerde kullanılan, yeniden doğuş, ikinci hayat gibi anlamsal değerler yüklenen diğer bir süsleme elemanı da "İstiridye Kabuğu"dur. Üst paleolitik dönemde mezarlarda cesetlerle birlikte istiridye kabuklarına rastlanılması yeniden doğuş kültürünün toplumsal yansımasıdır. Orta Asya'da, İskitlerin eserlerinde istiridye motifi görülmüştür. Hunların daha sonraki dönemlerde istiridyeden gerdanlıklara sahip oldukları saptanmıştır. Türklerin İslamiyet'i kabulüyle birlikte 11. yüzyılda istiridyeyi Suriye, Mezopotamya ve Mısır'daki eserlerde kullandıkları görülmektedir. Binaların cephelerinde, kapılarında, mihrap ve kubbeye geçiş elemanlarında farklı bir üslupla istiridye motifini kullanmışlardır. Örnek olarak, Harput Ulu Camii (1165) ve Diyarbakır Mesudiye Medresesi (1223) avlu mihraplarının kavsarası, Kayseri Gevher Nesibe Sultan Medresesi'nde (1205) oda kapılarında, Niğde Alâeddin Camisi'nin (1223) mihrap önü kubbesine geçişleri sağlayan tromplarda istiridye kabuğu süslemeleri gösterilebilir (Kuru (Çakmakoğlu), 2008, s.112-117). Nuruosmaniye Camisi'nin cümle kapısında (Fotoğraf 5), cümle kapısı duvar kalınlığı içerisindeki yan nişlerin alınlığında (Fotoğraf 6) ve güneybatı cephesindeki çeşmede istiridye kabuğu motifi bulunmaktadır (Fotoğraf 7).

Batı kökenli olan, aynı zamanda barok üslubun vazgeçilmesi olan "Girland", yaprak, çiçek, kumaş ve meyve motiflerinin iki nokta arasına asılmış 
bir kabartma şeklindeki süslemedir. Antik Yunan, Roma mimarisinde, Rönesans, Barok üslubunda görülür ve Türk mimarisine Batılılaşma sonrasında girmiştir (Sözen ve Tanyeli, 1999, s.91). Nuruosmaniye Camii minaresinin külah altında da iki katlı olarak yapılmış kumaş kıvrımlarından oluşan girland motifi yer almaktadır. Girlandların bağlı olduğu üst bölümde daire motifi yer alır. Aralarından da damla motifi sarkar (Fotoğraf 12).

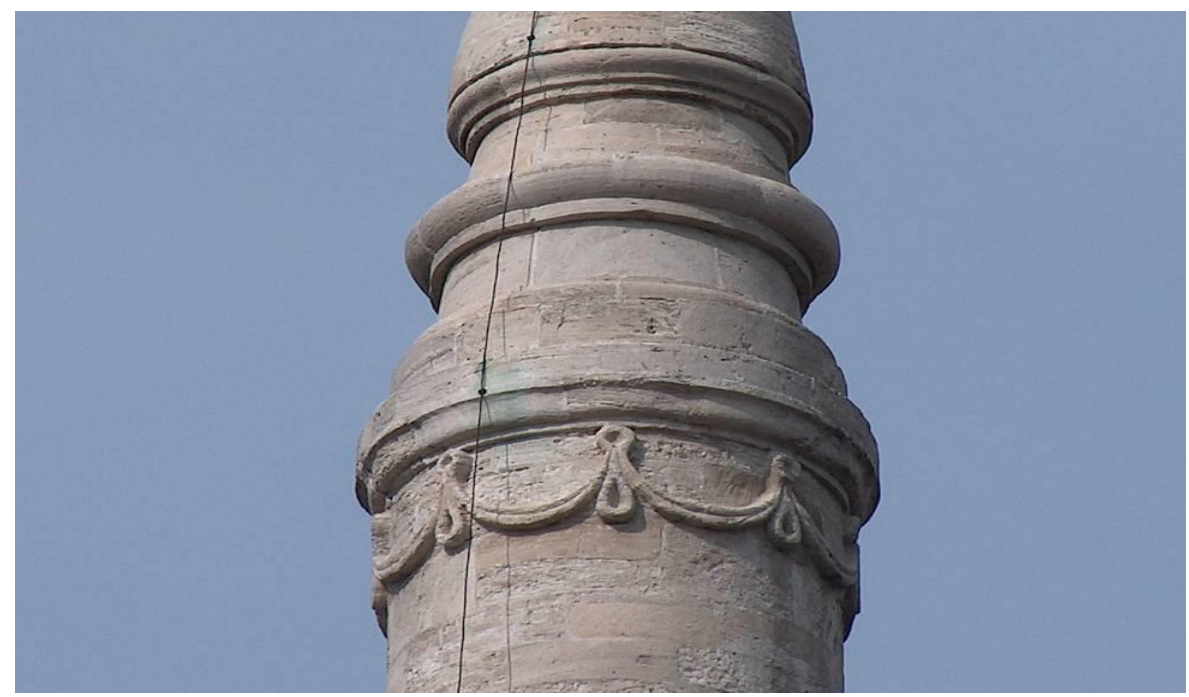

Fotoğraf12. Nuruosmaniye Camisi minaresinin külah altı

Nuruosmaniye camisi aynı dönemlerde yapılmış tüm camilerden her anlamda farklıdır. Nuruosmaniye'yi Osmanlı ve Batı sanatını bileşkesi üzerine kurulan bir kimliğin taş üzerine uygulanması şeklinde de değerlendirebiliriz.

Batıda görülen tüm unsurların Nuruosmaniye Camisi'nde hayat bulması, Osmanlıda batılılaşma eğiliminin bir göstergesidir: "Şekilli bir kornişle birleşen sütun başlıkları olan gömme sütunlar, deniz kabuğu motifleri, burmalı ve yuvarlak silmeler, içbükey ve dışbükey cepheler, çok sayıda pencere ve bunların yuvarlak ve çok dilimli kemerleri, hünkâr mahfili ve külliyenin diş kapısındaki barok çeşme" (Hammadeh, 2010, s.315, 317) örnek gösterilebilir.

Batı etkisi dışında, Osmanlı bu camiye aşevi, sebil, kütüphane ve dükkânlardan oluşan bir külliye ile kendi kültürel kimlik damgasını da vurmuştur. 
Osmanlı geç dönem süsleme sanatında sade üslup özelliklerinin yavaş yavaş kaybolduğunu, Osmanlı'daki kültürel değişimin sanata yansıdığını saptayabiliriz. Vazo içerisindeki çiçek ve meyve motiflerinin 18. yüzyıl mimarisinde ilk defa taşa uygulanması gibi.

Prizmatik öğelerden meydana gelen mukarnaslar, içbükey ve dışbükey silmelere dönüşerek "Barok Mukarnas" olarak adlandırılan süsleme elemanı Nuruosmaniye Camisinde karşımıza çıkmaktadır. Bu şekildeki uygulamaların sadece Nuruosmaniye Camisinde görülmesi ve diğer camii süslemelerinde fazla yaygın olarak yer almaması, bir bakıma bize bu dönemin özelliğini göstermektedir.

Sonuç itibarı ile, Nuruosmaniye Külliyesi dönem içerisinde yapılan genellemelerin ilkeler doğrultusunda, ilkelerin de kültürel miras ve Batı etkisi ile gelişerek melez Avrupai bir kültür ve sanat anlayışı şeklinde görüldüğü nadir yapilardandır.

Camilerde uygulanan süsleme sanatlarının menşei farklı uygarlıklardan olsa bile Türk İslam sentezi ile yoğrulmuş ve bir kültürel miras olarak sanat tarihinde yerini almıştır. Bu bakış açısı ile akantuslar, palmetler ve diğer çiçek süslemeleri İslam'a uygun olduğu için cami süslemelerinde görülmüştür. Ayrıca mukarnas süslemelerinde İslam'ın mistik anlamı, evrensel birlik ve denge düşüncesi de kurgulanmaktadır.

\section{Alg1 ve Olgu Olarak Nuruosmaniye Üzerine Genel Bir Değerlendirme}

Nuruosmaniye külliyesi Eminönü ilçesinde, Çemberlitaş' in kuzeybatısında, Bizans döneminde Constantinus Forumu olarak adlandırılan alanda, Kapalıçarşı'nın Nuruosmaniye Kapısı'nın doğu tarafında yer almaktadır (Gören, 1997, s.64).

Nuruosmaniye külliyesi yüksek bir tepe üzerinde inşa edilmiştir. Yunan sanatında kiliselerde ve binalarda görülen dik açı üçgeni ile yükseklik verilmiş, Osmanlıda ise şehrin her tarafından görülebilecek yerlere yapılarak caminin ulviyeti topluma yansitılmıştır.

Ticaret merkezinin içerisinde kapalı çarşının karşısında yer alan camii sosyolojik olarak ticaret erbabının, camii ile yakın irtibatı sayesinde cami ihtiyaçlarının giderilmesinde, o bölgede veya dışarıdan gelen ihtiyaç sahiplerine iaşe temininde, yemek verilmesinde büyük katkıları olduğu aşikârdır. Ayrıca külliyede bulunana müştemilat ile oradan gelip geçen halka, ticaret erbabının 
ihtiyaçlarına cevap vermektedir. Nuruosmaniye ile toplum arasında eş zamanlı bir ilişki vardır. Bu bağlamda konuyu Macionis şu şekilde bir ifade ile değerlendirmektedir: "Eğer gerçek anlamda sosyolojik boyutuyla bir kurumdan bahsediyorsak cevap verilen temel bir insani ihtiyaç bulunmalıdır ve bu cevapla kurumun ontolojik dayanağı açığa çıkmalıdır" (Akman, 2013, s.147).

Sanatın Nurusmaniye'de ve diğer camilerde halkın himayesiyle, himmeti ile kurumsallaştığını, vakıflar ve diyanet ile onların ontolojisinin belirlendiğini saptayabiliriz.

Nuruosmaniye Camisinin yerinde daha önce Fatma Hatun'un mescidi vardır. Zamanla eskiyen ve yıkılmaya mahkûm olan mescidin mahalle halkı tarafından Padişahtan tamiri istenmiş ve o günün şartlarında tamiratı uygun görülmemiştir.

Külliyenin tarihi süreç içerisinde incelendiğinde Sultan III. Ahmet ile başlayan serüven Sultan II. Mahmud ile devam etmiş ve kardeşi III. Osman döneminde tamamlanmıştır (Ongül, 1962, s.127).

Camiye kendi adına izafeten Nuruosmaniye adı verilmiş olup, kelimenin diğer çağrışım yapan yan anlamları ise "Nur" ve "Osmanlı İmparatorluğu" dur. Nur suresinde "Allah göklerin ve yerin nurudur. O'nun nuru içinde sşık bulunan bir kandil yuvası gibidir". Sosyolojik olarak değerlendirildiğinde Nuruosmaniye gelişigüzel bir isim olmayıp, bir zihnin düşünülmüş düşünceyi ihata etmesidir.

Külliyede bulunan cami, kütüphane, çeşme, medrese ve avlu toplumsal beklentilerin önemsendiğini göstermektedir. Külliyenin toplumun yoğun olduğu bir bölgede yer alması, halkın orada alışveriş öncesi ve sonrası dinlenmesi, dünyevî ve uhrevî ihtiyaçlarını giderebileceği bir yapı taşını oluşturmaktadır. Caminin güneyinde ve kuzeyinde bulunan iki cümle kapısı Kapalıçarşı'nın giriş kapısı gibidir. Çarşıya giren ve çıkanlar bu kapılardan geçerek cami avlusunda geçerler (Bahaaddin, 1966, s.62).

Camide namaz mekânunın klasik dörtgen şeklinde baldakendir olması, kalabalık bir cemaatin rahatlıkla ibadetlerini yerine getirebileceğini göstermektedir. Osmanlı dönemine genel olarak bakıldığında ibadethanelere, çeşmelere, hamam ve kütüphanelere ayrı bir önem verildiği görülür. Bununla bir bakıma toplumun sağlığı önemsenmiş olup, ibadethaneler (camiler) ruh, kütüphaneler zihin, çeşmelerle halk susuz bırakılmayıp hayatın kaynağı olmuş, hamamlar vücut temizliği ile sağlıklı bir toplumun yaratılması öngörülmüştür. 
Barok erken dönemi içerisinde İstanbul'da en iyi camileri arasında gösterilen Nuruosmaniye'dir. Bu durum I. Mahmut'un barok ve rokoko sanatına ilişkin duyduğu sempatidir (Cezar, 2002, s.272-273). Caminin barok eserleri arasında nadide bir eser olarak gösterilmesi, barok ve rokoko unsularının birleşmesi olarak görülebilir. Diğer taraftan Avrupa'dan barok mimarisinde getirilen şekiller klasik Türk biçimlerinin üzerine işlenmiş, camiinin ruhuna dokunulmamıştır (Kuran, 1963, s.418).

Barok üslubunun etkisiyle meydana gelen bu yapının iç avlusunda şadırvan bulunmamaktadır. Ancak güneybatı cephede, bugün camiye giriş olarak kullanılan kapının sağ tarafında çeşme bulunur. Çeşmenin sütun başlığı üzerinde akantus yaprakları ile sarmal kıvrımlar yer alır. Köşelerde ve ortada daire biçiminde yapılmış vazolar vardır. Çeşmenin kitabe yeri boş bırakılmış olup, çeşmenin teknesi ise rokoko üslubunda yirmi bir dilimli istiridye kabuğu bulunmaktadır (İlkhan Söylemez, 2010, s.81-82).

Caminin cümle kapısının her iki yanında bulunan sütuncelerin kaidesinde akantus yaprakları bulunmaktadır. Bu akantuslar yukarıya doğru dışbükey şeklinde kıvrılarak sarmal kıvrım oluşturmaktadır.

Süsleme sanatında kullanılan çiçek motifleri evrensel olmakla birlikte, İslamiyet'e özgü zihnin, kalbin ve aklın yansımalarını taşır. Çiçekler kokusu ve görünüşü ile güzeli, duruşu ile "sabrı" temsil eder. Zira nebatat âlemi hayvanat âlemi gibi nesebi peşinde koşmaz ve her şey kendi ayağına gelir. Hak ve hakikati düşünen insan her şeyin yaratıcı tarafından kendisine verildiğini idrak eder. Nebatat gibi olmak düşüncesinin taşıdığı anlam, nasibinde olan her şey sana mutlaka gelecektir. Bu nedenledir ki camilerde ki süsleme sanatı topluma ontolojik bir özgürlük bahşetmektedir diyebiliriz.

Camide ise çok sayıda pencere olup, pencereler strüktürel ögeler arasında kalan duvar yüzeylerine yerleştirilmiştir (Gören, 1997, s.68). Sanata ilişkin ilgi ve sempati Osmanlı padişahının İslam sanatında yer almayan barok üslubunu Nuruosmaniye'de uygulaması, sanatın ulusal ve uluslararası camiada özne konumunda olduğunu ve yeni perspektiflerin üretimine ruhsat verdiği anlamındadır. Bu durum tarihsel değişim ve dönüşüm süreçlerini başlattı̆ıın, İslami sanat anlayışında yeni sanat kültürünün benimsendiğini söyleyebiliriz. Bu nedenledir ki sanat kültürünün yasalarını belirleyen sadece sanatçı ve toplum olmayıp, aynı zamanda padişah, daha doğrusu siyasi otoriteler olduğunu da ifade edebiliriz. 
Nuruosmaniye Türk-İslam sentezi ile bütünleşen Barok ve Rokoko üslubu Türk Barok üslubunun doğmasına ve bir bakıma İslam'ın sınırları içerisinde özgürlük anlayışına da vurgu yapmaktadır. Zira akantus yapraklarının Hristiyanlığın ilk sembolü olarak kullanılması Osmanlı için bir engel teşkil etmemiştir. Hatta Hristiyanlığın semavi bir din olarak görülmesinin de tezahürüdür diyebiliriz.

\section{Sonuç ve Değerlendirme}

Sanatın, toplum, sanatçı ve siyasi otorite üçgeninde vücut bulması, miras olarak bırakılan Nuruosmaniye üzerinden düşünülmesi, yeniden yorumlanması, yeni bir ruh ve heyecan katması toplumun kültürel ve manevi değerlerini kuşkusuz yüceltecektir. Bu hakikat ve hakikate uygun toplum merkezli medeniyet, Nuruosmaniye Camisinde, sebillerle kütüphane ve abdest alma çeşmeleri ile kendini göstermektedir.

Tarihin her döneminde camilerin ve sanatın yasaları değişmemiş, her dönemde camiler fizikteki etki ve tepki şeklinde gerek ontolojik gerekse metafizik düşünce olarak irdelenmiştir.

Nuruosmaniye Camisi, insanı içerisinden dışına kadar kuşatacak estetik bir sanat anlayışının simgelemektedir. Bu sanat anlayışı, tüm toplum hayatına yayılacak manevi bir kültür oluşumunu da beraberinde getirmektedir.

Bu bakımdan, sanat toplumların ontolojik özgürlüklerinin korunmasında önemli bir role sahiptir. Sanatı, sosyolojik olarak anlamlandırmak, yaşanılan hayat tarzı ve kültür içerisinde karşılığı ile ilgili olup, genel geçerli alımlamalar farklılık gösterebilir. Nuruosmaniye camisinin yapısı, konumu ve süslemeleri ile "canlı bir kültür"e sahiptir. Zira sosyolojik anlamda estetik değerlerden ziyade, Nuruosmaniye külliyesinin insanların yaşamlarını kolaylaştırdığı gerçeği yadsınamaz.

Şehir hayatının içerisinde yer alan Nuruosmaniye Camisi, sosyolojik dönüşümlere meydan okurcasına bir simge olarak durmakta, insanda niçin var olduğumuzu ve olmamız gerektiğine dair bir düşünce uyandırmaktadır. 


\title{
EXTENDED ABSTRACT
}

\section{Nuruosmaniye Mosque in Terms of Art Sociology}

\author{
Duygu İlkhan Söylemez \\ Selçuk University
}

We can see the Nuruosmaniye Mosque as the integration of western and Islamic culture with its architecture and decorations. Mosques have an educational importance in finding and extracting the connection between the apparent and the batini of the society.

Due to its demographic structure, the people living around the mosque have changed in the historical process and have started to see "art" with the concepts of production and consumption, with modernity and materialistoriented ideas.

The main objective is to examine art in a sociologically dialectical way with cultural belonging codes of Nuruosmaniye Mosque. Here, to what extent analytical propositions will be identified with synthetic propositions are closely related to social expectations and society's understanding of art. Another sociological factor is the cultural change between the year the Nuruosmaniye was built and today.

We can say that the relationship between social perceptions and interpretations about Nuruosmaniye Mosque is two-way, circular and linear. The visible artistic aspect of the mosque is linear, while the postphysical aspect is circular. For this reason, evaluations as art-sociology are like the median between analytical propositions and synthetic propositions.

The main purpose of art sociology in this research is a short intellectual analysis of the tendency to see the inherent beauty of the human being and the contribution of the soul to spiritual satisfaction.

The effort to understand and make sense of art sociologically lies in the question of where is the metaphysics of art beyond the reality visible to the naked eye. This perspective is a cultural, traditional and temporal interpretation, and we can call it an interdisciplinary perspective.

When we look at the Nuruosmaniye Mosque in general, it is the first mosque to see a trend towards baroque. Nuruosmaniye Mosque, where the firsts are seen, is an example for the mosques built after it. For example; The 
entrance to the sultan's loge is externally ramped and is provided by a passage consisting of an L-shaped windowed corridor.

The fact that all the elements seen in the west came to life in the Nuruosmaniye Mosque is an indication of the westernization trend in the Ottoman Empire: The segmented arches, the sultan's loge and the baroque fountain on the outer door of the complex are examples.

Apart from the Western influence, the Ottomans left their mark on this mosque with a social complex consisting of soup kitchens, public fountains, libraries and shops.

Nuruosmaniye Complex is one of the rare buildings in which the principles are seen as a hybrid European understanding of culture and art, developing with cultural heritage and Western influence in line with the principles of generalizations made during the period.

Even though the origin of the decorative arts applied in mosques is from different civilizations, it has been kneaded with the Turkish-Islamic synthesis and has taken its place in art history as a cultural heritage. With this point of view, acanthus, palmettes and other flower decorations were seen on mosque decorations because they are suitable for Islam. In addition, the mystical meaning of Islam, the idea of universal unity and balance are set up in muqarnas decorations.

Nuruosmaniye complex was built on a high hill. In Greek art, the height was given with the right angle triangle seen in churches and buildings, and in the Ottoman Empire, the sublimity of the mosque was reflected in the society by building it in places that can be seen from all sides of the city.

The mosque, which is located in the trade center opposite the covered bazaar, sociologically, thanks to its close contact with the mosque, it is obvious that the merchants have a great contribution in meeting the needs of the mosque, in providing food to the needy people in that region or from outside. In addition, the outbuilding in the complex meets the needs of the tradespeople. There is a simultaneous relationship between Nuruosmaniye and society. In this context, Macionis evaluates the issue with a statement as follows: "If we are talking about an institution with a truly sociological dimension, there must be a basic human need to be answered, and with this answer, the ontological basis of the institution must be revealed." 
We can determine that art has been institutionalized in Nurusmaniye and other mosques with the patronage and patronage of the people, and their ontology is determined by the foundations and religious affairs.

Baroque and Rococo style, which is integrated with Nuruosmaniye Turkish-Islamic synthesis, also emphasizes the emergence of the Turkish Baroque style and, in a way, the understanding of freedom within the borders of Islam. The use of acanthus leaves as the first symbol of Christianity did not pose an obstacle for the Ottoman Empire. We can even say that it is a manifestation of Christianity being seen as a heavenly religion.

Nuruosmaniye Mosque symbolizes an aesthetic understanding of art that will encompass people from inside to outside. This understanding of art brings along a spiritual cultural formation that will spread to the whole community life.

In this respect, art has an important role in protecting the ontological freedoms of societies. Making sense of art sociologically is about life style and its counterpart in culture, and generally valid perceptions may differ. Nuruosmaniye mosque has a "vibrant culture" with its structure, location and decorations. It is undeniable that the Nuruosmaniye complex makes people's lives easier, rather than sociologically aesthetic values.

Located in city life, the Nuruosmaniye Mosque stands as a defiant symbol of sociological transformations and awakens an idea of why we exist and should be.

\section{Kaynakça / References}

Akar, A. (1969). Tezyini sanatlarımızda vazo motifleri. Vakiflar Dergisi, 8, 267-286.

Akman, M.K. (2013). İçtimai bir müessese olarak sanatın işleyişi sanat sosyolojisi'nin fikri dairesi içinde bir analiz. Karadeniz Teknik Üniversitesi Sosyal Bilimler Dergisi, 6, 145-148.

Anonim (1997). Palmet. Eczacıbaşı Sanat Ansiklopedisi, 3, 1424.

Bahaddin, O. (1966). Nuruosmaniye Camii. Hayat Tarih Mecmuast, 2(11), 58-62.

Bakır, B. (1999). XVIII. yüzyılda Türk Baroku Camileri. Osmanl Ansiklopedisi Kültür ve Sanat, 10, 265-275.

Barışta, H.Ö. (2000). Osmanl İmparatorluğu dönemi İstanbul'unda kuş evleri.1. Baskı, İstanbul: Kültür Bakanliğı Yayınları,

Bektaş, C. (2003). Kuş evleri. 1. Baskı, Literatür Yayınları, İstanbul.

Cezar, M. (2002). Osmanlı başkenti İstanbul. (1. Baskı). İstanbul: Erol Kerim Aksoy Vakfi. 
Değirmenci, K. (2017). Sanat sosyolojisi üzerine: Belirli kavramsal Gerilimler veikilikler. Yedi: Sanat, Tasarm ve Bilim Dergisi, 17, 1-9.

Doğru, M. (1987). Eminönü camileri. 1. Baskı, Türkiye Diyanet Vakfı Eminönü Şubesi Yayınları, İstanbul.

Gören, A.K. (1997). Nuruosmaniye Külliyesi. Art Decor, 4(47), 64-74.

Hammadeh, S. (2010). Şehr-i sefa 18 yüzyılda İstanbul (Çev.: İ. Güzel), İletişim Yayınları, İstanbul.

Hasol, D. (2002). Ansiklopedik mimarlık sözlüğ̈̈. Yem Yayınevi, İstanbul.

İkhan Söylemez, D. (2010). Batıllaşma dönemi İstanbul Cami cephelerinde taş süsleme (1703-1839). Doktora Tezi, Selçuk Üniversitesi sosyal Bilimler Enstitüsü, Konya.

Kuban, D. (1954). Türk barok mimarisi hakkında bir deneme. 1. Baskı, İTÜ Mimarlık Fakültesi Yayınları, İstanbul.

Kuban, D. (1981). Notes on the Building Technology 18th Century: The Building Mosque of Nur-u Osmaniye at İstanbul According to Camii Şerifi Nur-u Osmânî, 2nd International Congress on the History of Turkish-Islamic and Technology, 14-18 Eylül, İTÜ Yayınları, 271-293.

Kuban, D. (1995). Türk ve İslam sanatı üzerine denemeler. Arkeoloji ve Sanat Yayınları, İstanbul.

Kuran, A. (1963). XX. Yüzyıl'da batı mimarisiyle Türk mimarisinin gelmesi hususunda mukayeseli bir çalışma. Türk Sanatı Araştırma ve Incelemeleri, 1, 415-422.

Kuru Çakmakoğlu, A. (1997). Orta Asya Türk sanatında palmet ve lale motiflerinin değerlendirilmesi hakkında bir deneme. Belleten, 61-37, 52.

Kuru Çakmakoğlu, A. (2008). İkonografik açıdan ortaçağ Türk mimarisinde yer alan istiridye motifi. Erdem Dergisi, 52, 111-124.

Kürkçüoğlu, C. (1998). Şanlıurfa islam mimarisinde taş süsleme. Selçuk Üniversitesi Sosyal Bilimler Enstitüsü, Doktora Tezi, Konya.

Mülayim, S. (2006). Mukarnas. TDV İslam Ansiklopedisi, 31, 126-128.

Mülayim, S. (2012). Sanat sosyolojisi girişimleri. Sanat Tarihi Dergisi, 21(1), 97-109.

Ongül, A. (1962). Tarih-i Câmi-i Nuruosmânî. Vakıflar Dergisi, 5, 127-146.

Ögel, S. (1992). 18. ve 19. yüzyıllarm Osmanl Camilerinde geleneksel anlama katkıları. Semavi Eyice Armağan, 269-280.

Özbek, Y. (2002). Osmanlı Beyliği mimarisinde taş süsleme (1300-1453). 1. Baskı, Türk Tarih Kurumu Basımevi, Ankara.

Söylemez, A . (2021). Yerel Yönetimler ve Erişilebilir Kentler: Sağlıklı Kentler Birliği'ne Üye Belediyeler Örneği. Akademik Araştırmalar ve Çalışmalar Dergisi (AKAD), 13 (24) , 78-88 . DOI: 10.20990/kilisiibfakademik.886650, 78-88. 
Söylemez, A., Şahin, A. (2018). Türkiye'nin Sanayi Politikası, Türkiye'de Kentsel Alan ve Çeore Politikası Analizleri (Ed: E.Akman, C. Babaoğlu), Ekin Basım Yayın, 323348.

Sözen, M.,Tanyeli, U. (1999). Sanat kavram ve terimleri sözlüğü. Remzi Kitabevi, 5. Baskı, İstanbul.

Tanyeli, G, Tanyeli, U. (1989). Osmanlı mimarlı̆ı̆nda devşirme malzeme kullanımı (1618. Yüzyll), Sanat Tarihi Araştrmalan Dergisi, 4, 23-31.

Ulusoy, D. (1993). Sanat sosyolojisinde temel yaklaşımlar. Hacettepe Üniversitesi Edebiyat Fakültesi Dergisi, 10(1), 247-259.

\section{Kaynakça Bilgisi / Citation Information}

İlkhan Söylemez, D. (2021). Sanat sosyolojisi açısından Nuruosmaniye Camisi. OPUS-Uluslararası Toplum Araştırmaları Dergisi, 17(37), 46774701. DOI: $10.26466 /$ opus. 866536 